Western University

Scholarship@Western

Education Publications

Education Faculty

2013

\title{
Plurilingualism in TESOL: Promising Controversies
}

Shelley K. Taylor

The University of Western Ontario, tayshelley@gmail.com

Kristin Snoddon

University of Alberta

Follow this and additional works at: https://ir.lib.uwo.ca/edupub

Part of the Education Commons

Citation of this paper:

Taylor, S. K., \& Snoddon, K. (2013). Plurilingualism in TESOL: Promising controversies. TESOL Quarterly, 47(3), 439-445. doi: 10.1002/tesq.127 https://onlinelibrary.wiley.com/doi/abs/10.1002/tesq.127 
Plurilingualism in TESOL: Promising Controversies

\author{
SHELLEY K. TAYLOR \\ Western University \\ London, Ontario, Canada \\ taylor@uwo.ca
}

\title{
KRISTIN SNODDON
}

University of Alberta

Edmonton, Alberta, Canada

snoddon@ualberta.ca

The idea for this special issue grew out of the editors' involvement in TESOL's ESL in Bilingual Education Interest Section (BEIS). As we respectively took leadership roles within BEIS, we took part in BEIS' record of "pushing the boundaries to make way for a more multilingual TESOL" (Taylor, 2009, p. 310). While Shelley co-conducted a survey of TESOL members regarding the need for a multilingual language policy within TESOL (Taylor, Smith, Daniel, \& Schwarzer, 2009); Kristin spearheaded a resolution regarding Deaf learner's language rights that subsequently became a TESOL (2009) Position Statement. These activities were rooted in the belief that learners' linguistic repertoires have a crucial role to play in learning English. This special issue's focus on plurilingualism, or multilingualism at the level of the 
individual (Council of Europe, 2001), is intended to further illuminate the role and value of learners' and teachers' first languages (L1s) and additional languages, and policies that support their plurilingual repertoires in relation to TESOL's mission of advancing excellence in English language teaching in a highly diverse, multilingual world.

As we undertook the work of this special issue, we were aware that we were promising controversies on several fronts. Since the 1950s, TESOL has faced controversies regarding the status of languages other than English within the organization (Fishman, 2009). From a practitioner's perspective, the idea of including a learner's L1 in the classroom is still viewed cautiously, as a recent online discussion on "What is the role of L1 in L2 teaching?" on TESOL's LinkedIn platform shows (Mokhtar, 2013). Bilingual education remains so marginalized in concept and practice that plurilingualism is a radical notion in many respects (García, O., personal communication, 2013). As with other radical ideas, plurilingualism can offer us both explanatory power and moments of freedom.

In terms of the former, researchers have observed that many long-accepted models and concepts in the fields of bilingualism and bilingual education cannot account for situations of extreme linguistic complexity (e.g., Skutnabb-Kangas, Phillipson, Panda, \& Mohanty, 2009). In current contexts of globalization and migration, this superdiversity is linked to unpredictable and unprecedented variation in individual linguistic repertoires (Blommaert \& Backus, 2011; Vertovec, 2007). Superdiversity is also linked to digital transformation of multilingual communication practices (Ito et al., 2010). In recent years, other authors have coined the terms translanguaging (García, 2009), translingualism (Canagarajah, 2013), and polylanguaging (Jørgensen, 2010). Each of these concepts describes the multiple discursive practices that plurilinguals engage in as they make meaning with one another. In doing so, plurilinguals also 
challenge standard notions of languages as fixed and discrete entities. A paradigm shift in TESOL may also be observed on several fronts, with the British Council now publishing such works as the Juba declaration ${ }^{1}$ that commit it to mother-tongue-based multilingual education (Coleman, 2011; Skutnabb-Kangas \& Heugh, 2011), several participants on the LinkedIn discussion supporting L1 use in TESOL, and many of the contributors to this special issue discussing a need for change. Therefore, there appears to be a change in the wind as increasing recognition of the need to account for plurilingual repertoires becoming the zeitgeist.

As evidenced by this special issue, practitioners are increasingly drawing on learners' full linguistic repertoires in a variety of TESOL settings. These range from a case study of plurilingual teaching practices in Uganda by Doris Maandebo Abiria, Margaret Early, and Maureen Kendrick, and a study in Hong Kong by Angel Lin. The international focus of this special issue is significant given that prior research on plurilingualism has primarily been conducted in Europe. Only recently have researchers such as Ofelia García begun crossreferencing the development of the construct in North America, although there are historical antecedences such as Suresh Canagarajah's focus on plurilingualism as an ages-old, natural occurrence in certain Eastern contexts. ${ }^{2}$ Plurilingualism in TESOL entails a paradigm shift that opens new approaches to understanding teaching and learning. Its status as a construct and practice that is a work in progress reflects its place in a time of paradigm shift, and is commensurate with its vision of language learners' linguistic repertoires as fluid and dynamic.

\footnotetext{
${ }^{1}$ See http://englishagenda.britishcouncil.org/policy-fora/english-language-mother-tongueeducation-and-language-policy-and-planning

${ }^{2}$ For more details, see Rashi Jain's review of Canagarajah (2013), this issue.
} 
However, plurilingualism remains controversial in both concept and practice for several reasons that are explored in this issue. For one, there remain questions concerning the distinction between plurilingualism and multilingualism. In their paper regarding the plurilingual and multimodal competences of first-year university students in Vancouver, Canada, Steve Marshall and Danièle Moore address this distinction head on. As these authors write, "we use 'plurilingual(ism)' to refer to the unique aspects of individual repertoires and agency, and 'multilingual(ism)' to refer to broader social language context/contact(s) and the co-existence of several languages in a particular situation" (this issue). In contrast to traditional definitions of multilingualism that focus on separate language proficiencies, as Marshall and Moore argue, "the focus on plurilingual competence not only allows researchers to dismantle perceptions of arbitrary boundaries within individuals' linguistic repertoires, but also this focus relates to broader issues such as individual agency, knowledge formation, and engagement" (this issue).

Thus might we imagine a world without languages as static systems that work to divide and to perpetuate social hierarchies However, a main difficulty with this line of thinking, as Diane Potts outlines in her paper for this issue's Symposium, is that for many minority groups around the world, their languages are already endangered. As Potts writes, "[i]n choosing to privilege a more expansive understanding of students' linguistic resources, we may sometimes inadvertently risk obscuring our failure to support individuals in developing their more fragile languages" (this issue). Additionally, as Nelson Flores cautions in his paper, there remains the danger that plurilingualism as language policy can be appropriated in service of a neoliberalist, corporate agenda. Problems with appropriating the rhetoric of plurilingualism in language planning in local contexts are also outlined by Fiona Willans in her paper regarding Vanuatu's language education policy. 
Further issues arise in regard to plurilingualism's challenge to standard conventions of academic English. Particularly in terms of high-stakes writing assignments and testing, it appears that these standards are entrenched. Plurilingualism remains limited in concept and practice unless and until it is seen as permissible to breach these standards, such as by allowing the use of code-meshing (Canagarjah, 2006, 2011) in the production of academic English texts. In this issue, the papers by Abiria et al., Lin, and Marshall and Moore present cases where students make use of their plurilingual competences toward the production of English texts, albeit according to standard academic English norms. In addition, Elizabeth Ellis' paper presents empirical arguments for the need for plurilingual teachers in TESOL settings. This issue's Forum and Symposium provide further examples from around the world of how plurilingualism operates in the TESOL classroom.

In their Forum paper regarding the European context, Jasone Cenoz and Durk Gorter challenge the monolingual ideology present in many English-only classrooms as they urge for the boundaries between languages to be softened. Similarly, Enrica Piccardo's lead Symposium paper calls on us to revisit our assumptions regarding monolingualism and bilingualism as she puts forward the argument that we are all plurilingual: "No matter how monolingual we consider ourselves to be, we are fundamentally plurilingual, albeit unconsciously so. No matter how 'standard' and 'pure' we consider each language, it is inevitable that they are all ensembles of different elements in a dynamic and constantly changing relationship" (this issue).

The six Symposium papers responding to Piccardo present practical examples of plurilingualism in practice, including Goodith White, Chefena Hailemariam, and Sarah Ogbay's study of a "homework club" run by Eritrean immigrant parents in Manchester, U.K., where peer teaching in Tigrinya and English takes place outside of mainstream schooling. Heather 
Lotherington's paper further outlines the link between plurilingualism and multimodal practices in a Canadian classroom setting of extreme linguistic complexity, while Rita Elaine Silver and Wendy Bokhorst-Heng and discuss hybridity and plurilingualism in a Singaporean context where language planning for multilingualism is predicated on monolingual norms. Gudrun Ziegler, Natalia Durus, and Olcay Sert provide a fascinating glimpse into how students at the European School of Luxembourg enact their plurilingual repertoires via a word search exercise in Englishmedium, content subject teaching. Ziegler et al.'s study of a learning context where students have different first languages is reminiscent of Taylor's (2013) work on mother-tongue-based multilingual education in Nepal, a context characterized by extreme linguistic complexity and a paucity of resources, which in turn raises questions for plurilingualism. How do financial and logieal constraints, and the need to engage with students' full plurilingual repertoires influence how plurilingual pedagogies and policies may be implemented in diverse contexts? To this point, Saskia Stille and Jim Cummins' study of Canadian elementary students in an urban setting highlights how learners may integrate their home languages into digital literacy activities. As Stille and Cummins write, 'language teaching can draw on the full range of students' cultural, linguistic, and representational skills and abilities as a foundation for learning, and as a means to promote new forms of participation in the contemporary linguistic landscape" (this issue).

Thus we return to plurilingualism's moments of freedom, as rather than chafing at monolingual ideologies, language learners are offered what the poet Amit Mujmudar (2012) calls the opportunity to "Recombine, become a thing / of your own creation." In undertaking this special issue, our aim was to promulgate such moments for learners and teachers as much as it was to urge a paradigm shift in thinking about the place of other languages in TESOL. The time is ripe as there is a palpable zeitgeist and related (if separate) manifestations of plurilingualism, 
whether they are termed thusly or as translingualism, polylanguaging, or simply multilingualism. Indeed the four books reviewed in this special issue-Klaus Börge Boeckmann, Eija Aalto, Andrea Abel, Tatjana Atanasoska \& Terry Eric Lamb’s (2011) Promoting plurilingualism. Majority language in multilingual settings, reviewed by Colette Despagne; Suresh Canagarajah's (2013) Translingual practice: Global Englishes and cosmopolitan relations, reviewed by Rashi Jain; Marilyn Martin-Jones, Adrian Blackledge and Angela Creese, Editors' (2012) The Routledge handbook of multilingualism, reviewed by Robert Phillipson and Tove SkutnabbKangas, and Claire Thomas' (2012) Growing up with languages: Reflections on multilingual childhoods, reviewed by Kristin Snoddon—all touch on various aspects of, and research on, the role and value of learners' and teachers' L1s and additional languages, and policies that support plurilingual repertoires in relation to English teaching and learning. We hope practitioners and researchers alike will find much on offer here to enhance their understanding of language teaching and learning.

\section{Acknowledgements}

We gratefully acknowledge the discussions we had on the topic of plurilingualism from the proposal stage to the completed issue with Jim Cummins, Ofelia García, David Little, and Robert Phillipson, and acknowledge their generosity in completing reviews. We also sincerely appreciate the time, expertise, and goodwill of the following reviewers: Carol Benson, Suresh Canagarajah, Alister Cumming, Yvonne Freeman, Anna Ghimenton, Kathleen Heugh, Anne Holmen, Kendall King, Hans-Jürgen Krumm, Mario López-Gopar, Ahmar Mahboob, Ajit Mohanty, Céline Peigné, Martha Pennington, Mela Sarkar, Jeeweon Shin, Kelleen Toohey and Manka Varghese. We acknowledge Jens Normann Jørgensen, Suresh Canagarajah, and Tove 
Skutnabb-Kangas' pioneering work, and support for this special issue. We remain grateful for our ongoing discussions with fellow members of TESOL's BEIS/TEDS Interest Section and their dedicated support for plurilingual learners, teachers, and policies. Finally, we would like to thank Diane Belcher, Alan Hirvela, and Meaghan McDonnell for their ongoing support with guest editing this special issue of TESOL Quarterly, and doctoral candidates Vickie Wai Kei Li and Dawn Fyn, Western University, for assistance with preparing the manuscript.

\section{The authors}

Shelley Taylor is Associate Professor at Western University. Her research focusses on plurilingual learners in educational language programs out-of-step with superdiversity in Canada and Denmark, and in innovative programming in Nepal. She has published in the Canadian Modern Language Review; International Journal of Bilingualism \& Bilingual Education; Race, Ethnicity \& Education, and Writing \& Pedagogy.

Kristin Snoddon is the David Peikoff Chair of Deaf Studies at the University of Alberta. Her work focuses on American Sign Language, early literacy, and related sociolinguistic issues. Her

publications include American Sign Language and Early Literacy: A Model Parent-Child Program (Gallaudet University Press, 2012). 


\section{References}

Aftat, M. (2013, April). What is the role of L1 in L2 teaching? Message posted to http://www.linkedin.com/groups/What-is-role-L1-in$\underline{3733067 . S .225572121 \text { ? view }=\& \text { srchtype }=\text { discussedNews \&gid=3733067\&item }=225572121}$

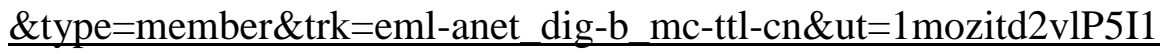

Blommaert, J., \& Backus, A. (2011). Repertoires revisited: 'Knowing language' in superdiversity. Working Papers in Urban Language \& Literacies. Tilburg University, the Netherlands.

Canagarajah, S. (2006). The place of world Englishes in composition: Pluralization continued. College Composition and Communication, 57(4), 586-619. Retrieved from http://mjreiff.com/uploads/2/9/1/7/2917319/canagarajah.pdf

Canagarajah, S. (2011). Codemeshing in academic writing: Identifying teachable strategies of translanguaging. Modern Language Journal, 95(3), 401-417. doi: OI: 10.1111/j.15404781.2011.01207.x

Canagarajah, S. (2013). Translingual practice: Global Englishes and cosmopolitan relations. London: Routledge.

Coleman, H. (2011). Developing countries and the English language: Rhetoric, risks, roles and recommendations. In H. Coleman (Ed.), Dreams and realities: Developing countries and the English language (pp. 9-21). London: British Council. Retrieved from http://www.teachingenglish.org.uk/sites/teacheng/files/Z413\%20English\%20Development \%20Book.pdf

Council of Europe. (2001). A Common European Framework of Reference for languages: Learning, teaching, assessment. Cambridge, UK: Cambridge University Press. 
Fishman, J. (2009). Is a fuller relinguification of TESOL desirable? TESOL Quarterly, 43(2), 313-317. doi: 10.1002/j.1545-7249.2009.tb00170.x

Ito, M., Baumer, S., Bittanti, M., Boyd, D., Cody, R., Herr, B., Horst, H. A., Lange, P.G., Mahendran, D., Martinez, K. Pascoe, C. J., Perkel, D., Robinson, L., Sims, C. and Tripp, L. (2010). Hanging out, messing around, geeking out: Living and learning with new media. Cambridge: MIT Press.

Jørgensen, J. N. (2010). Languaging: Nine Years of poly-lingual development of young TurkishDanish grade school students, vol. I-II. Copenhagen Studies in Bilingualism, the Køge Series, vol. K15-K16. University of Copenhagen.

Mujmudar, A. (2012). To the hyphenated poets. The New Yorker, September 17, 86.

Skutnabb-Kangas, T., \& Heugh, K. (Eds.). (2012). Multilingual education and sustainable diversity work: From periphery to center. New York: Routledge.

Skutnabb-Kangas, T., Phillipson, R., Panda, M., \& Mohanty, A. K. (2009). MLE concepts, goals, needs and expense: English for all or achieving justice? In A. K. Mohanty, M. Panda, R. Phillipson \& T. Skutnabb-Kangas (Eds.), Multilingual education for social justice: Globalising the local (pp. 313-334). New Delhi: Orient BlackSwan.

Snoddon, K. (2012). American Sign Language and early literacy: A model parent-child program. Washington, D. C.: Gallaudet University Press.

Taylor, S. K. (2013). From "monolingual” multilingual classrooms to "multilingual" multilingual classrooms: Managing cultural and linguistic diversity in the Nepali educational system. In D. Little, C. Leung \& P. Van Avermaet (Eds.), Managing diversity 
in education: Key issues and some responses. (pp. 259-274). Clevedon, UK: Multilingual Matters.

Taylor, S.K. (2009). Paving the way to a more multilingual TESOL. TESOL Quarterly, 43(2), 309-313. doi: 10.1002/j.1545-7249.2009.tb00169.x

Taylor, S. K., Smith, P., Daniel, M., \& Schwarzer, D. (2009). Is there a need for a language policy and heightened multilingualism in TESOL? Survey results. Bilingual Basics, 11(1). Retrieved from http://www.tesol.org/read-and-publish/newsletters-otherpublications/interest-section-newsletters/bilingual-basics/2011/11/03/bilingual-basicsnews-volume-11-1-(december-2009)

TESOL. (2009). Position statement on the rights of Deaf learners to acquire full proficiency in a native signed language. Retrieved from http://www.tesol.org/s_tesol/bin.asp?CID=32\&DID=12563\&DOC=FILE.PDF . Vertovec, S. (2007). Super-diversity \& its implications. Ethnic \& Racial Studies, 30(6), 10241054. doi: 10.1080/01419870701599465 